\title{
DE CRUCE CHRISTI REPRESENTATIONES IN AUREUM SAECULUM: VALENCIA, PATÓN, CALDERÓN ET ALII
}

\author{
POR \\ JUAN C. GONZÁLEZ MAYA \\ Universidad Islas Baleares \\ glezmaya@yahoo.es
}

\begin{abstract}
RESUMEN
Las representaciones y el uso de la Cruz de Cristo han sido múltiples y variadas a lo largo de la historia de la religión y la cultura. El artículo que se presenta se centra en un recorrido histórico de este significado, haciendo especial hincapié en el siglo XVII. En este itinerario particular se explorarán los intentos de regulación del símbolo cristiano por excelencia por parte de altas instituciones del estado y de algunos preceptistas religiosos molestos por la indecencia de su uso en la vida cotidiana.
\end{abstract}

PALABRAS ClaVE: Cruz de Cristo; Edictos Inquisición; Bartolomé Jiménez Patón; Preceptistas religiosos.

\section{DE CRUCE CHRISTI REPRESENTATIONES IN AUREUM SAECULUM: RIBERA, VALENCIA, PATÓN ET ALII}

\begin{abstract}
The representations and the use of the Cross of Christ have been multiple and varied through religion and culture's history. The article presented here focuses in a historical trajectory, especially in the XVII century. During that century, there is a display of attempts to regulate the Christian symbol par excellence by the state's high institutions and some religious theorists bothered by the impact of its daily use.
\end{abstract}

KEY WORDS: Cross of Christ; Inquisition Edicts; Bartolomé Jiménez Patón; religious theorists.

$\begin{array}{ll}\text { Recibido/Received } & \text { 24-10-2013 } \\ \text { Aceptado/Accepted } & \text { 07-10-2014 }\end{array}$

\section{INTRODUCCIÓN}

Quisiera apuntar brevemente en este artículo la trascendencia de algunos textos del primer tercio del siglo XVII que mostraban su preocupación por el símbolo cristiano por excelencia, la santa cruz, y por el escándalo que suscitó entre los moralistas su uso indecente. Para ello trazaré un breve recorrido histórico y me centraré en algunos discursos significativos que nos revelarán las formas de esa inquietud.

En una época convulsa en lo político, pero rearmada en lo religioso, la simbología de la cruz representaba para la religiosidad popular de aquel tiempo un rasgo fundamental como centro de la devoción cristiana, pero también como elemento de cohesión social. Así, pues, en las próximas páginas voy a repasar de qué manera estaba presente en la vida social de la primera mitad del siglo XVII, qué textos influyeron en esa orientación y algunas de sus manifestaciones más significativas.
En esta época, una vez acabada ya con la última disidencia morisca $(1615)^{1}$ y prácticamente sin herejes a los que combatir, la Iglesia barroca española se vuelca sobre todo en la expresión más exterior y visual del sentimiento religioso, extendiéndose hacia toda la sociedad y la cultura en un supremo intento de llevar hasta el extremo una suerte de religión nacional, rigurosamente controlada. Su autoridad la convierte así en celosa guardiana de la doctrina contrarreformista, que preconizaba especialmente una pedagogía basada en la represión y el castigo cuando fallaba la persuasión. Su vasta influencia sobre las artes plásticas y la literatura, y su importante vertiente predicativa, $^{2}$ en cuanto a

1 Según Kamen, entre 1615 y 1700, «las persecuciones de moriscos constituyeron el 9 por 100 de los casos juzgados por la Inquisición» (2004: 221).

2 «El Siglo de Oro de la oratoria sagrada», según Núñez Beltrán (2000: 35). 
la salvación de las almas, consiguieron hacer todavía más palpable y directa su implantación. No voy a entrar ahora en la predicación sagrada, pero sí en algunos de los textos que sustentaban esta doctrina.

Son inabarcables los escritos de la época sobre el significado del símbolo cristiano, muchos de ellos apologéticos, literarios o no. Mi intención no es tanto relacionarlos, sino comentar algunos casos relevantes cuya preocupación principal residía en el respeto que se debía tener al venerable madero y los lugares donde debía estar presente o prohibido. El papel de las instituciones, en este sentido, resulta fundamental. Su impacto estaba fuera de toda duda por la capacidad de control que eran capaz de ejercer: control de pensamiento, pero también de costumbres en una sociedad, no lo olvidemos, donde la religión estaba fuertemente implantada. Si lo religioso impregnaba firmemente todos los ámbitos de la vida cotidiana del individuo de aquel tiempo, exhortándolo a cumplir con los diferentes preceptos, incluyendo la vía coercitiva, fácil es pensar en disposiciones que regularan tales conductas.

\section{EDICTO DE LA INQUISICIÓN}

En este contexto, pues, de obsesión, cabe ubicar un edicto del Supremo Consejo de la Santa Inquisición ${ }^{3}$ surgido presumiblemente como respuesta a los abusos e irreverencias en los que había caído el empleo de la sagrada insignia, o como consecuencia directa de algunas peticiones como la del humanista Pedro de Valencia (1609), que luego comentaré, por su relevancia como precedente. Sea de una manera o de otra, la Inquisición, una vez más, actuaba de oficio contra toda práctica religiosa o de pensamiento "desviada» o ajena a su ortodoxia, publicando una orden expresa en los siguientes términos:

Hacemos saber que, debiendo estar la Santa Cruz siempre puesta y colocada con la reverencia y veneración que se debe, se ha introducido un abuso y perniciosa costumbre de poner y pintar cruces en rincones públicos y secretos y otros lugares indecentes con fin de preservarlos de las inmundicias ordinarias, ocasionándose por este camino muchas indecencias e irreverencias que se experimentan por ignorancia o inadvertida irreverencia.

Por tanto, para evitar los dichos inconvenientes y otros mayores indignos de tolerarse entre fieles y católicos cristianos, y en especial en estos reinos donde la santa fe católica está y debe estar con tanta pureza, por la presente ${ }^{4}$ mandamos a vos y a cualesquier de vos que dentro de nueve días primeros siguientes después de la publicación destas nuestras letras, o que dellas supiéredes en cualquier manera, que os damos por tres términos canónicas moniciones ${ }^{5}$ y el último por peremptorio, ${ }^{6}$ so pena de excomunión mayor y de docientos ducados para gastos del Santo Oficio; borréis y quitéis todas y cualesquier cruces, así pintadas como hechas de madera o otra

3 Recordemos que en el emblema de la Institución lucía como motivo central un madero de la cruz, flanqueado por una rama de olivo y una espada. Me ha resultado imposible dar con la fuente del edicto. El texto que transcribo a continuación lo tomo de La decente colocación de la Santa Cruz, de Patón, quien lo reproduce.

4 por la presente: desde aquí hasta «peremptorio» es formulística legal que encontramos en numerosos edictos y sentencias de la época. moniciones: 'avisos o amonestaciones'.

6 peremptorio: 'último plazo, sin posibilidad de apelación'. cualquier materia que cada uno tuviere o hubiere puesto o pintado o hecho poner y pintar por su orden en dichos lugares o tuviere en las casas suyas o de su habitación y morada, así en poblado como en los campos o heredades, así de particulares como de comunidades a quien tocare. Que de aquí adelante ninguna persona las ponga ni pinte, haga poner o pintar en ellos ni en otros lugares y partes indecentes.

Y no lo cumpliendo en el dicho término, pasa los dichos nueve días o contraviniendo en adelante, os damos por incurridos en las dichas penas y censuras, y procederemos a ejecución dellas y de otras mayores, como hallaremos por derecho.

Dada, etc. ${ }^{7}$

Hoy se conoce el edicto gracias a su inclusión en el opúsculo de otro humanista, el maestro Bartolomé Jiménez Patón: Decente colocación de la Santa Cruz (1635, fols. 29v30r), libro al que dedicaré amplio comentario en la segunda parte de este artículo. Es difícil precisar con exactitud la fecha de este importante documento al no haber podido dar con la fuente, y porque, además, no consta en el impreso consultado y Patón tampoco la facilita, no obstante, cabe ubicarlo, con total certeza, en el período 1621-1626. La primera fecha porque Patón expresa que Felipe IV lo manda publicar; la segunda, por la publicación el 20 de octubre de 1626 en Ciudad de Méjico de otro edicto de la Inquisición de Nueva España que cabe suponer consecuencia del anterior, puesto que copia fragmentos y recurre a las mismas fórmulas legales. ${ }^{8}$ Dado que el humanista habla de «un nuevo edicto» (fol. $3 \mathrm{v}$ ), cabe pensar más en una datación cercana a la escritura de su opúsculo que no en una lejana; por tanto, aventuro finales de 1625 o principios de 1626, en tiempos del inquisidor general Andrés Pacheco de Cárdenas. ${ }^{9}$

\section{DE EXHORTACIONES Y BURLAS VARIAS}

Como se desprende de su lectura, el Santo Oficio entra en el asunto para regular y corregir algunas costumbres que considera perniciosas y que estaban ampliamente difundidas entre la población. Recordemos que la vida cotidiana de los ciudadanos de aquel tiempo estaba fuertemente tutelada por la Iglesia. Su preocupación principal viene determinada por la práctica bastante común de pintar o colocar cruces en determinados lugares para «preservarlos de las inmundicias ordinarias», ensuciando paredes y rincones con las necesidades de los particulares. El hecho ya era un lugar común por aquellos años, como se puede comprobar en el célebre Vocabulario de refranes y frases proverbiales de Gonzalo Correas, publicado poco después del decreto, en 1627, aludiendo precisamente en su entrada («Pusiéronle cruz porque no le measen») a la prohibición mencionada que ya entonces debía de ser bastante conocida: «Malicia contra uno de hábito que no era de buen talle, sino chico y

7 Transcribo siguiendo los criterios de la edición que estoy preparando según el impreso de 1635 de Jiménez Patón, Decente colocación de la Santa Cruz (fols. 29v-30r), modernizando las grafías del texto, salvo en aquellos casos que tuvieran relevancia fonética.

8 Alonso, 1977: 31, lo reproduce.

9 Obispo de Segovia e inquisidor general entre 1622 y 1626 . Cfr. Fernández Collado, 2000: 69 y el Nobiliario genealógico de los reyes y títulos de España, 1622: 180. 
feo. Solíanse poner cruces en rincones de patios y zaguanes porque no measen en ellos; mas ya está justamente mandado que no se pongan y borrar las que estaban pintadas en deshonestos lugares». ${ }^{10}$

Abundan los ejemplos donde se menciona la fea costumbre a lo largo de toda España. Rodríguez Marín comenta a propósito de Sevilla en los preliminares de su edición de Rinconete y Cortadillo: "[...] Y si es de los rincones y parajes solitarios, no se diga cómo estaban: baste recordar que desde el año 1599 se acudió al socorrido expediente de pintar o poner cruces en las paredes de tales sitios, cosa que en dos o tres años se hizo tan general, que no quedó rinconada de templo ni de calleja sin aquellas pinturas». ${ }^{11}$

Que a pesar de las penas impuestas, el edicto tuviera el efecto deseado no se sabe porque se desconoce el tipo de control ejercido, aunque es de suponer que como protectores de la moralidad pública cuyo impacto en la vida cotidiana era determinante, el poder de los inquisidores debió de hacerse notar. No obstante, la costumbre no desapareció por completo. Aparecen varios ejemplos en fechas posteriores. Por ejemplo, en el entremés de Quiñones de Benavente Las nueces, publicado en 1643, se lee lo siguiente: "Sale un Vejete con un tiesto de almagre. Vengo a poner unas cruces / en el rincón de mi puerta, / que la pudren los muchachos / cuando salen de la escuela» (vv. 228-231)..$^{12}$ Lo que demuestra que el hábito todavía no estaba erradicado del todo.

Pero si nos remontamos en el tiempo, el suceso o chiste ya era moneda común en tiempo de los Reyes Católicos a propósito del apellido Rincón. En un escrito burlesco muy celebrado por haber circulado en numerosas copias manuscritas e impreso en ediciones posteriores, ${ }^{13}$ atribuido al poeta y diplomático Diego Hurtado de Mendoza, titulado Carta del bachiller de Arcadia, y respuesta del capitán Salazar, se menciona el chiste de Rincón el viejo e Isabel la Católica. Esta, cuando va a imponerle el hábito de Santiago recibe la siguiente respuesta: «Su Alteza me ha hecho poner esta cruz porque no se meen en mí». ${ }^{14} \mathrm{El}$ chiste, anécdota o cuentecillo, ${ }^{15}$ circuló ampliamente como lo demuestra esta letrilla atribuible a Góngora donde se adapta el contenido:

A don Diego del Rincón, cojo, ciego y corcovado, un hábito el Rey le ha dado, con encomienda de León.

Bien le vino al andaluz, que en tal Rincón cosa es clara que cualquiera se meara si no le viera la cruz. ${ }^{16}$

10 Edición digital A. Zafra, refrán 19251

11 1920: 62.

12 El entremés apareció por primera vez en la colección Entremeses Nuevos de diversos autores para honesta recreación, Alcalá de Henares, Francisco Ropero, 1643, fols. 50-57v. Cito por mi edición de la compilación de 2012, pp. 239-259.

13 Existe un estudio interesante sobre la autoría, fecha, manuscritos, ediciones y contenidos de las Cartas en Varo Zafra, 2010: 433-472.

14 Paz y Melia, 1890: 81. La carta y la respuesta ocupan las págs. 63-99.

15 Chevalier, 1999: 231.

16 Millé y Jiménez, letrilla atribuible XLIV, p. 454.
Lo que viene a demostrar que la costumbre de pintar o colocar cruces para no ensuciar paredes era antiquísima. Por el juego de palabras, se colige que se adapta una chanza ya conocida, y que hay que remontarla como mínimo a 1504, año del fallecimiento de Isabel I de Castilla. Sería inútil dilucidar fechas sobre la costumbre, su antigüedad es mucho mayor, de origen medieval y, quizás, pagano. Mezclar a los dioses con el acto escatológico era moneda corriente entre los romanos quienes pintaban dos culebras, en alusión a Esculapio, para preservar algunas paredes o rincones de las inmundicias y orines, como nos recuerda Persio, ${ }^{17}$ antecedente manifiesto de las modernas cruces. Del mismo modo que estas sustituyeron a las imágenes de Mercurio en las confluencias de los caminos durante los primeros tiempos del cristianismo "para deslucir y borrar las supersticiones gentílicas». ${ }^{18}$ La sustitución de un uso pagano por otro cristiano con el mismo fin es un hecho que saluda Patón porque estaba al servicio de una doble finalidad: al tiempo que se hacían desaparecer los "falsos dioses» o la «necia idolatría», se originaban lugares de devoción para el buen cristiano. La conversión la ilustra el humanista con otros ejemplos, como el nuevo uso de la mezquita de Córdoba y otros más.

Un ingenio afilado como Francisco de Quevedo, contemporáneo y amigo de Patón, ${ }^{19}$ no podía dejar escapar el potencial que le sugería el singular y popular uso. De 1603, según Astrana Marín, ${ }^{20}$ es su Carta a una monja, que da inicio así:

Por estas cruces suplico a vuestra merced, mi señora doña Ángela, que no rasgue antes de leerla esta carta que, aunque parece cimenterio o procesión de Semana Santa, no es sino que de miedo que por despreciarla no se orinen en ella, la he llenado de cruces como rincón de la iglesia. ${ }^{21}$

Como ya ha quedado indicado, la práctica llegó a propagarse extraordinariamente por la expansión de lo español al nuevo continente, creando lógicamente la misma preocupación. Así que la cruz llegó a convertirse entonces en un hábito para conjurar las aguas menores en paredes varias, lugares oscuros, callejones o incluso muros exteriores de las iglesias. Jiménez Patón también se hace eco de este problema de salubridad e irreverencia y en su Decente colocación de la Santa Cruz, aunque recalca que algún sitio tiene que haber donde "vacíen los muchachos y vulgo sus inmundicias, estiércoles y basuras», propone algunas soluciones que hoy serían harto polémicas, basadas en curiosos cambios: sustituir el símbolo cristiano por otros iconos más rechazables como un demonio, un ídolo, un Príapo o un Mahoma escuálido. ${ }^{22}$ En cualquier caso, el piadoso procedimiento de los vecinos para evitar ver sus paredes sucias, debía refrenar a los viandantes a vaciar allí sus necesidades, por el respeto al símbolo sagrado.

17 “"Prohíbo -exclamas- que aquí hagáis porquerías". Tú pinta dos serpientes. "Chicos, el lugar es sagrado; ja mear a otra parte!"» (Sátira ı: 113-114).

18 Patón, 1635, fol. 23v.

19 Ambos se admiraban mutuamente y residieron durante algún tiempo en Villanueva de los Infantes, donde ejercía Patón (Madroñal, 2009a: 26-27). Ver también nota 44.

20 Obras en verso, p. XIX.

21 Prosa festiva completa, ed. Celsa C. García Valdés, 1993: 257.

22 1635, fol. 25 
Pero el edicto mencionado, además de afear la «perniciosa costumbre» y las "indecencias e irreverencias» que su uso ocasionaba, tenía también carácter punitivo: conminaba a borrar o quitar todas las cruces de los lugares indecentes y a no poner ni pintar ninguna más en esas partes "so pena de excomunión mayor y de docientos ducados para gastos del Santo Oficio». No era esta la primera ocasión en que se pronunciaban las instituciones con la misma intención sancionadora. Años antes ya se habían producido otros intentos en la misma dirección. En 1578, san Juan de Ribera, el gran impulsor de la expulsión de los moriscos de $1609,{ }^{23}$ arzobispo de Valencia, patriarca de Antioquía y modelo de los contrarreformistas, dejó constancia en el primero de los sínodos valencianos de la preocupación existente sobre la colocación de las cruces en los rincones públicos en su Decreto Sinodal «Ne crucis et sanctorum imagines in immundis locis depingantur" (Decreta Synodi. Actio prima) ${ }^{24}$ La importancia de este documento radica en que reproduce unos cuarenta y ocho años antes las mismas inquietudes y sanciones que recogería el edicto de Felipe IV: preocupación por el uso irreverente de la santa insignia, mandato de no poner ni pintar cruces ni imágenes sagradas en paredes o rincones, de borrar o quitar las dichas cruces y pena de excomunión mayor a la desobediencia. Pero cuando san Juan de Ribera menciona las «imágenes santas», también se está refiriendo a otros iconos disuasorios pintados en paredes de lugares públicos, como los de san Antonio Abad en el claustro alto de las Escuelas Mayores de la Universidad de Salamanca contra las aguas menores de los estudiantes..$^{25} \mathrm{El}$ hecho dio lugar incluso a una frase proverbial que recoge Gonzalo Correas en su Vocabulario de refranes: "Pintar santantones en rincones y llamas", donde glosa: "como en las escaleras de escuelas mayores de Salamanca para amenaza al que se atreviere a mear en tal lugar». ${ }^{26}$ El gramático Antonio de Nebrija, quien estudió y ejerció como docente en esa universidad, en sus comentarios a la Sátira I de Persio recuerda también el hecho: «Así también en nuestro tiempo pintamos una imagen de san Antonio o de la Cruz del Señor en aquellos lugares donde se prohíbe hacer aguas menores y mayores».27 Francisco del Rosal (1560?-1610?) nos ilustra en La razón de algunos refranes los motivos de la práctica: "Santantones en los rincones y lugares donde queremos se guarde limpieza. Fue antigua costumbre amenazar con enfermedades a los que se ensuciaban o orinaban en lugares donde se pretendía hubiese limpieza. Y así pintaban un Sto. Antón con llamas de fuego, significando el fuego que dicen de Sto. Antón, enfermedad en aquel tiempo temida y asquerosa». ${ }^{28}$

23 Según H. Kamen, «el más implacable enemigo de los moriscos» (2004: 219).

${ }^{24}$ Synodus diocesana Valentiae celebrata, praeside illustrissimo ac reverendissimo D.D. loanne Ribera, Patriarcha Antiocheno \& Archiepiscopo Valentino. Valencia, Pedro de Huete, 1578, fol. 37.

25 Hoy todavía se conserva la imagen. Se puede ver en un rincón, junto a la Biblioteca. Aparece con báculo y cirio encendido y se cree atribuida a Juan de Flandes (Rodríguez, 2004: 427).

26 Ed. cit., refrán 18380.

27 El texto procede de los comentarios de Nebrija a la Sátira I de Persio, 113-114 (Sevilla, lacobus Kromberger, 1504).

28 1976: 158-159. Rodríguez Marín, incluso, recoge la frase «Alguacil ponte santantones porque no se meen en ti» en su Un millar de voces castizas y bien autorizadas que piden lugar en nuestro léxico (1920: 251).
Ciertamente muchas paredes debieron convertirse en auténticos urinarios si no se utilizaban imágenes santas o cruces con fines de limpieza. Tal era el concepto de higiene que tenían entonces los numerosos viandantes que no podían contenerse.

En términos similares a san Juan de Ribera, aparece en 1606 las Constituciones Sinodales del Obispado de Valladolid, donde en su título XIX, De Reliquiis et veneratione Sanctorum, la Constitución I expresa: "Que no se pinten ni esculpan cruces ni imágenes en el suelo ni en los rincones». ${ }^{29} \mathrm{El}$ documento, más completo que los anteriores, es posible que sirviera de base a otros sucesivos. Las primeras palabras de la constitución sinodal vallisoletana vienen a recoger el mismo principio de 'alarma social' manifestado por el edicto de la Inquisición:

Porque de la costumbre que hay de poner o pintar cruces en los rincones, portales y paredes de las iglesias de la parte de afuera, y aun de algunas casas y calles, para evitar que en aquellas partes no se echen o derramen inmundicias, por la veneración que se les debe tener, no solamente no se consigue el fin que se pretendía, mas se da ocasión a mayor irreverencia y desacato de la santa insignia. ${ }^{30}$

\section{Pedro de Valencia}

En esta sucesión de peticiones y prohibiciones cabe mencionar una de las más significativas, por la categoría del personaje, el gran humanista y erudito Pedro de Valencia, cronista de Felipe III, entre otros muchos cargos, y amigo de Luis de Góngora; ${ }^{31}$ quien, en carta fechada en Madrid el 5 de agosto de $1609^{32}$ y dirigida al arzobispo de Toledo don Bernardo Sandoval y Rojas, ${ }^{33}$ a la sazón Inquisidor General de España (1608-1618), solicita su intervención para que actúe contra el abuso de poner cruces «en muchas partes por las calles y casas donde hay rincones y lugares acomodados para que los que pasan se puedan retirar a orinar de día y hacer otras mayores inmundicias de noche» (fol. 1v). La carta, que ocupa tres folios y medio a doble columna, puede considerarse todo un pequeño tratado sobre el símbolo cristiano por excelencia, sin abandonar en todo momento el tono de protesta y denuncia por su uso irreverente en la Corte.

Justifica Valencia su petición con una disertación inicial sobre el valor y significado de la Santísima Insignia en la historia de España, la gratitud que se le debe por los numerosos beneficios recibidos, como en las milagrosas apariciones en las batallas contra los infieles, y la «indecencia y falta de veneración debida, sino en desprecio y abatimiento» en que

\footnotetext{
29 Cito por la impresión de Pablo Miñón de 1803, p. 242.

$30 \quad$ Ibídem, p. 242
}

31 Autor de la primera censura gongorista a petición del poeta cordobés. Famosas son sus epístolas Carta de Pedro de Valencia escrita a don Luis de Góngora en censura de sus poesías, de 1613, y la Censura de las Soledades, Polifemo y obras de don Luis de Góngora, hecha a su instancia.

32 Discurso dirigido al Arzobispo de Toledo sobre que no se pongan cruces en los lugares inmundos. BNE, ms. 11160, fols. $1 \mathrm{r}-4 \mathrm{r}$. Los ejemplos que cito a continuación son transcripción directa de la consulta de ese documento. Parece que, aunque el discurso se ha citado en varias ocasiones, todavía permanece inédito.

33 Fue su amigo y consejero hasta la muerte del prelado en 1618 (Gómez Canseco, 1993: 74). 
ha caído el sagrado símbolo en las calles y casas de la Corte, como en los casos de «infieles, herejes o moros a propósito se lleguen y orinen y hagan otras suciedades»; ${ }^{34}$ pero no solo de infieles sino de los «mismos que profesamos y enseñamos debérsele dar adoración [...] la tratamos con mayor desprecio que ellos que le niegan todo culto», dirigiendo sus dardos contra sus propios contemporáneos, acusándolos de falsa religiosidad.

El escándalo lo considera, pues, Valencia mayúsculo, "cosa muy indigna y horrenda que se vea esto entre cristianos y en la Corte del Rey Católico». Con este planteamiento, acude en las siguientes páginas de la carta a ejemplos y leyes de diferentes autoridades civiles y eclesiásticas, como papas, reyes, emperadores u hombres santos para ilustrarnos sobre la rectitud de su uso, la devoción debida y para reprimir el mal uso. Se transcriben entonces algunos decretos a favor de la cruz, como en los casos de los emperadores Teodosio y Valentiniano, del sínodo de Constantinopla (680-81), de san Luis rey de Francia, de don Juan I en las cortes de Briviesca y de los papas Pío IV y Gregorio XIII, algunos los repetirá Patón en su opúsculo; aunque en ninguno se contemplaban las prácticas denunciadas por Valencia en la capital del reino, porque si así fuera «aquellos príncipes y prelados santos abominaran y prohibieran con mayor detestación de palabras y gravedad de penas». ${ }^{35}$ En la parte final de la curiosa disertación se relacionan algunas prácticas del mundo antiguo, entre romanos y judíos, para revelarnos sobre cómo se solucionaban estos problemas en aquel tiempo. Acaba la parte expositiva con una simple comparación para subrayar la gravedad del asunto: se pregunta qué pasaría si en lugar de imágenes santas se colocaran retratos de reyes o ministros, "sería crimen lese majestatis», ${ }^{36}$ concluye.

Después de la exposición de motivos, precedentes y muestras mencionadas, se expresa en el último párrafo la súplica encarecida al arzobispo de Toledo, Inquisidor mayor, para que corrija «un abuso tan abominable con censuras [...] so penas graves para que se ejecute en toda España». La valoración de este documento viene determinada por la importancia de los personajes en escena y de que esa petición posiblemente no cayera en saco roto. Aunque no figuran fechas y no me ha sido posible dar con ningún otro edicto por esos años, sabemos por Patón de un decreto de Felipe III en el que «se despacharon por todo el reino cédulas en que mandaba Su Majestad que se quitasen y borrasen las cruces de todos los lugares indecentes $"{ }^{37}$ diferente al de su sucesor el cuarto Felipe aunque con idéntica prohibición al que es objeto el presente estudio.

Nuestra historia, por tanto, cuenta con una serie de peticiones o de protestas de personajes significativos por el irrespetuoso empleo de un símbolo cristiano tan significativo, y de consiguientes y repetidas disposiciones en esa dirección, consecuencia directa o no de tales peticiones. La posición dominante de la Iglesia en aquella sociedad y su potestad como censora se constituían, una vez más, en garantes del comportamiento religioso.

34 Al contrario que Juan de Ribera, no era partidario de la expulsión de los moriscos, sino de su integración, como contempla en su Tratado acerca de los moriscos.

35 Op. cit., fol. 3.

36 Op. cit., fol. $3 \mathrm{v}$.

37 1635, fol. 8.

\section{BARTOLOMÉ JIMÉNEZ PATÓN}

En el contexto, pues, de un país convulso, lastrado por las guerras y dominado por la influencia de la Iglesia, la institución máxima, a los ojos del humanista, ${ }^{38}$ se inscribe la Decente colocación de la Santa Cruz (impreso en 1635, pero con licencia del Ordinario de noviembre de 1628, por tanto siete años en los que permaneció en el limbo), ${ }^{39}$ texto profundamente imbuido de una retórica cristiana propia de los tratados morales de su tiempo; natural, por otra parte, si tenemos en cuenta que su autor era un hombre de fuertes convicciones religiosas y muy apegado a la ortodoxia tridentina.

Consta el librito de ocho hojas de preliminares y de treinta y dos folios, y puede considerase, sin lugar a dudas, una de las más importantes contribuciones al uso de la cruz en un sentido más amplio que el que he venido considerando hasta ahora. No obstante, aunque gran parte del tratado se ocupa de hacer un repaso histórico de la colocación de la cruz con numerosas citas de autoridades civiles y religiosas y de las Sagradas Escrituras, propio de la compilación acumulativa de los saberes en su tiempo, el origen del libro, su núcleo central, venía motivado, una vez más, por su uso indecente, no solo en paredes y rincones sino en otros múltiples lugares que el Maestro describe con detalle.

El escrito es contemporáneo al decreto mencionado de la Inquisición de 1625-26, al que alude como «nuevo edicto». Cabe, por tanto, inscribir ambas tentativas como parte de una misma ofensiva, aunque el opúsculo del humanista no se escribió para formar parte de ninguna esfera preceptiva, labor esta que correspondía a la Suprema. ${ }^{40}$ En esa época, pues, Patón dio cumplimiento a dos de los mandamientos principales de la que era su familia: ${ }^{41}$ el de guardián de la herejía y el de protector de la moralidad pública, ${ }^{42}$ circunscribiendo así su trabajo en pos de la unidad de la fe, pero también en una parcela social coercitiva, en vez de otra más libre, expresión personal de una devoción más sentida o profunda. Esta última línea, de fértil creatividad entre los místicos del siglo anterior, se vio cercenada por el firme atrincheramiento de la iglesia postridentina, más preocupada por las prohibiciones o los castigos que por el impulso espiritual, separándose así de lo místico para hacerse cada vez más terrenal. Patón se inscribe en esta línea, al ser

38 La figura de Jiménez Patón se ha ido revalorizando en los últimos años gracias al monumental ensayo de Abraham Madroñal, Humanismo y filología en el Siglo de Oro. En torno a la obra de Bartolomé Jiménez Patón, y a los artículos de Jaume Garau («Ideas religiosas del Maestro Bartolomé Jiménez Patón (1569-1640)», «No hay mayor desigualdad que hacerlo todo igual» o "El humanismo de Bartolomé Jiménez Patón»). Además de la edición conjunta de los Comentarios de erudición. Libro decimosexto, de los que doy cuenta puntual en la bibliografía. Finalmente, tengo previsto publicar durante 2017 una edición crítica de los discursos no filológicos de la obra del manchego.

39 La diferencia entre el pie de imprenta y la época de redacción era algo habitual en las obras de Patón, como ya han estudiado los profesores Madroñal (2009a: 128-130) y Garau (2012a: 603).

40 Al que alude el escritor para indicar que ese edicto se escribió para que los hombres vivan «más advertidos que hasta ahora» (fol. 30v). Exhortación que puede entenderse también en su sentido más coercitivo.

41 Patón llegó a ser notario de la Inquisición en Murcia en 1616.

42 Kamen, 2004: 84. 
consciente de que la expresión de la religiosidad entre amplios sectores de la población se canalizaba a través de manifestaciones externas, de formas populares del comportamiento religioso, al amparo de la Roma contrarreformista que preconizaba esa exteriorización o, incluso, ostentación de la fe. Es entonces cuando cobra una especial relevancia el predominio de unas pautas de conducta exteriores que, como hemos visto con el edicto de la Inquisición, se aplica en rigurosas normas de control social.

Sobre las fuentes de inspiración, es razonable pensar que el catedrático de elocuencia tuviera presente la mayoría de las que se han relacionado hasta ahora, más alguna otra como la descripción histórica que Justo Lipsio hizo en su librito De Cruce (1593), cuyo detallismo en la descripción de los tormentos sobre la cruz y demás refinamientos de la crueldad es sobrecogedor, sobre todo si tenemos en cuenta su relación de amistad con Quevedo, y de este con el influyente Lipsio, ${ }^{43}$ a su vez guía de varios textos de Patón; ${ }^{44}$ pero su opúsculo va en otra dirección. Por ello, si se tuviera que destacar una fuente, la principal, sin duda, sería el escrito de 1609 de Pedro de Valencia, porque, a pesar de su reducida extensión, contiene todos los elementos del discurso del manchego: el primero, el motivo principal, el escándalo suscitado entre una parte del clero y algunas figuras relevantes de la cultura por la imprudencia en la colocación de la cruz en lugares tachados de 'indecentes', provocando su reacción y dando pie al objetivo principal de este tipo de discursos: la reforma de los abusos que sufre la Santa Cruz. En segundo lugar, el elogio del significado de la santa insignia en la historia de España, bien por los milagros producidos o por el éxito en la lucha contra el infiel; en tercer lugar, descripción de algunas prácticas similares en el mundo antiguo. A continuación, la apelación a señaladas autoridades civiles y religiosas que, a lo largo de la historia, regularon su uso; y, finalmente, el requerimiento o ruego para la reparación de los excesos cometidos.

Esta misma estructura, con abundantísimos ejemplos, algunos repetidos de Valencia, y numerosas citas en latín, es la que se observa en la Decente colocación. Pero, además de la reconocida facilidad erudita del humanista, las quejas enunciadas se traducen, en otro nivel de significado, en un acercamiento a la realidad más inmediata a la que continuamente se alude, con historias, anécdotas, vivencias, tradiciones... que también hacen del discurso un valioso documento para la pequeña historia de la vida cotidiana de los ciudadanos del siglo XVII.

Una de estas anécdotas es la que da inicio al escrito, y la que da pie a toda la disertación. Todo empieza, pues, por un hecho aparentemente baladí, que pasaría desapercibido en cualquier otra ocasión: la crítica de unos desconocidos «algunos» que reprochan al intelectual el no dibujar la señal de la cruz en los sobres de sus cartas familiares, como todo buen cristiano. No se sabe si realmente le escoció la censura, pero la anécdota llega a convertirse a lo largo de todo el discurso en un motivo recurrente ante el que el escritor siente la necesidad imperiosa de justificarse una y otra vez. Con lo cual lo que parece latir en el fondo es un asunto de mayor calado: el ejercicio de la pedagogía emanada de los

43 Véase Lida, 1958: 157-162. Sobre la relación Quevedo-Patón, Madroñal, 2009a: 26-27; 2009b: 372, 376.

44 Garau, 2012: 615. principios contrarreformistas, tan característico de su obra y de su época, y el carácter obsesivo de la religiosidad barroca. Sin entrar de lleno en la predicación, ${ }^{45}$ se comparte con esta el mismo afán de control ideológico o de adoctrinamiento social conocido. Volveré sobre ello más tarde.

Pero sigamos con el caso de las cruces en los sobrescritos y de los motivos que se arguyen para no dibujarlas. Patón, aquí, hace suyo el criterio del dominico fray Alonso de Santillán, quien desaconseja su empleo porque el papel puede emplearse «en ministerios indecentes y aún indignos de nombrarlos». ${ }^{46}$ Por lo que razona el humanista que «no es justo que con ese peligro se ponga cruz ni, como otros añaden, el dulcísimo nombre de Jesús, nuestro bien, y María, su Madre santísima, en lo alto de la carta ni en el sobrescrito». Concluyente juicio, por lo que la resolución parece lógica: «mas que se escriba o selle el nombre de Jesús en las cartas téngolo por peligroso y temo no pare en una tal indecencia». Tales aseveraciones hoy las podríamos tachar apresuradamente de ridículas, pero deben ser leídas y percibidas en el marco de la mentalidad de la época.

Como se ve, el celo desmesurado o la potestad censora de la institución religiosa llevó a la expresividad de lo religioso a auténticas cotas de obsesión o exageración con la excusa de la "reforma de abusos», de la salvación del alma o de la muralla para defender la ortodoxia contra la herejía u otras desviaciones. Como el culto se practicaba de manera rigurosa y puntual, resultaba imprescindible establecer unas pautas de conducta bien concretas. Patón, en este sentido, tampoco fue original. El gran tema recurrente de su opúsculo, el uso de cruces pintadas en las paredes o erigidas en el suelo para evitar inmundicias, ya había recibido tratamiento y quejas en escritos de años anteriores, como se ha visto; no obstante, era lógico que levantara la voz ante los desafueros cometidos, especialmente si se tiene en cuenta la consideración especial que le tenía al madero sagrado: "porque en ella tenemos la salud, la paz, la verdadera libertad, la vida, la gracia, la sabiduría, la justicia, la santificación del género humano y el remedio universal de todos los siglos presentes, pasados y venideros» (fol. 25v).

Otra de sus preocupaciones sobre los usos irreverentes del símbolo del cristianismo, se centra en su colocación en el suelo en lugares o formas donde podía ser pisada, tal como decía también en su carta Pedro de Valencia. Por este motivo censura las lápidas funerarias, las alfombras, los escritos con cruces, como las cartas, incluso las marcas en los lomos de las reses, porque al tumbarse estas también son causa de indecencia, haciendo acopio de testimonios civiles y eclesiásticos, como los de los emperadores Teodosio II y Valentiniano III, san Luis Rey de Francia, Pío IV o san Carlos Borromeo, quienes legislaron sobre ello. ${ }^{47}$

45 Su labor docente y su Perfecto predicador (1612), en Madroñal, 2009a: 191-276, le abocan a ello.

46 La cita es una respuesta verbal del fraile dominico a una pregunta de Patón (fol. 9v de la Decente).

47 Son los mismos personajes que ya veíamos en la carta de Valencia, con la diferencia que Patón traduce el edicto de los emperadores romanos. El edicto de Teodosio y Valentiniano lo encontramos en el Códice Justiniano, libro primero, título VIII, publicado en el año 427; el de Pío IV en un decreto sobre las imágenes sagradas de 1563 (Denzinger, 2006: 554-556); el de san Carlos Borromeo, en uno de los Concilios Provinciales que presidió en Milán, posiblemente el tercero, de 1573, aprobado por Gregorio XIII. 
Todos ellos, salvo en el caso de los emperadores romanos, deudores del Concilio II de Nicea, donde en su séptima sesión, de 13 de octubre del 787, se proclamó la «Definición sobre las imágenes sagradas» (Denzinger, 2006: 282-283).

Las citas de autoridades civiles y eclesiásticas con veneración a la Santa Cruz son una característica del estilo del opúsculo-librito, siguiendo la tradición de otros tratados de cruce. Ellas son las que marcan los juicios al tiempo que ponen de relieve el grado de erudición, religiosa o no, de Jiménez Patón y las relaciones personales y epistolares que mantuvo con elevados representantes eclesiásticos, de lo que hace gala en alguna ocasión. No obstante, cabe decir también que la acumulación de citas de autores clásicos o de la Biblia era un sello característico del humanista contrarreformista, quien empleaba esas voces de autoridad para sustentar las más diversas opiniones. ${ }^{48}$

En su línea argumentativa, el Maestro refuta, corrobora, amplía o profundiza al hilo de los testimonios que va desgranando, manifestando con ello sus convicciones religiosas y su enorme respeto a las autoridades, especialmente la Iglesia, en su parecer, la autoridad máxima. Hombre de profunda religiosidad, en ningún momento se aparta de la verdad oficial. Se muestra particularmente interesado con los ejemplos en latín de celebridades religiosas (el 50\% del total) en las cuales revela una profunda devoción a Cristo y al venerable madero, casi como centros exclusivos de plegarias; pero también su conocimiento de la lengua clásica. De las treinta y ocho que he podido localizar en lengua romance (veintiuna directas y diecisiete indirectas), treinta y una son de fuente religiosa. La Biblia se convierte en el libro de referencia por excelencia, en tanto que lo es de autoridad.

Si se tiene en cuenta que la religiosidad popular es el comportamiento más frecuente de la expresión religiosa, Patón estimó necesario que los consejos exhibidos tuvieran un buen soporte fundamentado de «piadosos y doctos varones» porque su doctrina "es santa y se debe tener y guardar como ellos lo enseñan y aconsejan» (fol. 2v). Este conjunto de opiniones más las esbozadas por el propio humanista se inscribían en la línea de otros similares que también aspiraban a reforzar la cohesión social de grupo, fuente y manifestación de la devoción popular. Así, las citas de los santos varones inciden en el aspecto de arma defensiva contra el pecado y las dificultades o peligros, aunque en algunos casos se prodiguen excesivamente los consejos de Tertuliano al exhortar al uso de la señal de la cruz en casi toda situación: al andar, al vestirse, calzarse, lavarse, sentarse o ante las velas que alumbran... San Jerónimo la aconseja como arma para conservar la virginidad; san Ambrosio se preocupa por las heces y suciedades sobre el símbolo cristiano; los emperadores Teodosio y Valentiniano la prohibieron sobre lápidas; Paulo Diácono cuenta en su Miscelánea cómo el emperador Tiberio II, al quitar una cruz de una lápida, se encontró con un «gran tesoro». También se relacionan los escrúpulos de un desconocido licenciado Ávila, ${ }^{49}$ alarmado por ver papeles

48 Madroñal, 2009b: 362; y, especialmente, Caro Baroja, para quien «no siempre la gran erudición humanística va unida al criterio más prudente [ ] El método "acumulativo» le basta» (1978: 56).

49 Posiblemente Esteban de Ávila Álvarez (Ávila, 1549-Lima, 1601), teólogo, profesor y jesuita que fue nombrado calificador de Santo Oficio en 1600 . Sus dos obras más importantes, varias veces ree- con cruces en envoltorios varios: "los entregan a boticarios o tenderos para envolver ungüentos o otras cosas, las cuales acabadas dan con el papel en el suelo cuando no lo echan en lugar más indecente, que es común en aposentos de enfermos»; o los de fray Jerónimo Román al verla en jarras de refectorios de monasterios, «porque aunque allí parecen bien, después, si se desportillan y no son para servicio en las comunidades, usan dellos en cosas indecentes y poco honestas». Con estos y otros capítulos, se intenta estrechar el círculo de obsesiones y penetrar en los más recónditos órdenes de la vida ordinaria. Así, se llega a desaconsejar su uso en las chimeneas, en las puertas traseras de las viviendas y en las de los corrales; encima de setos; en las cercas de viñas o ranchos; en casas de campo; en la entrada de hosterías, posadas, ventas o mesones y en las ventanas y puertas en general.

Entre tantas insignificancias que perturbaban el espíritu de nuestro intelectual católico y el respeto que provocaba la sola mención de la Santa Inquisición, es normal que con escritos como este y similares, se corrigieran estos hábitos entre el pueblo. Su librito salió como comentario del edicto de la Suprema y a él se acude con la reproducción de varios fragmentos. Por ello, en vez de extenderse en más casos de irreverencias o imprudencias varias o de que la gente pensara que se prohibían todas las cruces, Patón, como contrapartida, también hace notar las acciones o las situaciones en que considera justo y conveniente su presencia. Lo único que consigue, en este sentido, es recordar lugares comunes ya consabidos, como el santiguarse al levantarse de la cama, al salir de casa, al oír truenos, al entrar a un templo o ante cualquier peligro, costumbres que hoy todavía se conservan. Sobre su colocación da su consentimiento a los mástiles de los barcos, a los escudos, banderas, armas, vestidos (como los de las órdenes militares), monedas, coronas de emperadores, tiaras de papas, calvarios, vía crucis, templos, oratorios y albergues de los pobres; colgadas en el pecho, en el cuello, en los rosarios o en las manos de los exorcistas; en fin, como señales de caminos y en los cadalsos. Nada que cualquier feligrés de la época no conociera fehacientemente. Su esmero, en cambio, llega a desechar por no pernicioso aquellas situaciones o lugares en los que accidentalmente podía formarse el venerable madero, como en los casos de palillos, pajas u hojas secas del suelo o en las rejas de las ventanas y algunos maderos de las puertas.

Junto al tratadito sobre los lugares decentes e indecentes de la colocación de la Santa Cruz, y del establecimiento de las pautas exteriores de conducta bien claras, a modo de ejercicio o control riguroso sobre el bien y el mal, subyace todo el entramado ideológico, religioso o doctrinal que sustenta la parte más exterior o visual, así como hasta ahora se ha comentado.

No hay que olvidar la importante labor de la Iglesia, especialmente en el siglo XVI, aunque también en la época en la que escribe Patón por desterrar la superstición, que estaba muy extendida en su tiempo. De hecho, el uso estimado como incorrecto del símbolo de la cruz entraba poderosamente en esta preocupación. También los alumbrados,

ditadas, son: De censuris ecclesiasticis tractatus (Lyon, 1608) y Compendium Summae seu Manualis Doct. Navarri (Lyon, 1609) (O’Neill, 2001: 305). 
en concreto en el proceso a María de Cazalla, mujer de la alta sociedad y una de sus más destacadas activistas, se aborda la cuestión del valor que otorgaban los iluministas al símbolo de la cruz, opuesto al culto establecido. En el proceso inquisitorial que sufrió excluía la adoración de las imágenes, llegando a afirmar «que Dios quería ser adorado en espíritu y no en templos por mano y arte». ${ }^{50}$

Es en este punto donde se acude a «la razón de la erudición», como se lee en las primeras líneas, y donde se hace más visible el propósito didáctico, al que, en cierto modo, le obligaba el magisterio de su labor docente. Para conseguir el propósito aleccionador se acude a varios tópicos como el miedo a la infección herética, muy recurrente en toda su obra, o al topos tradicional de la vida cristiana como milicia (fol. 30v), del miles christianus (no en la lectura erasmista) al servicio del "Dios de las batallas» (fol. 9) en permanente lucha contra los enemigos de la fe: «temporales, espirituales, infieles paganos, necios idólatras, herejes, turcos mahometanos o cismáticos». Este es un argumento tan antiguo como la Biblia. En los escritos de Jeremías se atestiguan numerosas citas del Dios de las batallas, de las venganzas, de las represalias o de las iras; y en la Epístola a los Efesios de san Pablo $(6,10-17)$, al definir la armadura del cristiano, se fijaron los términos de esta singular contienda en permanente lucha contra el Maligno. De forma que en la literatura occidental, ambos tópicos han gozado de amplia difusión y copiosa recreación literaria, conformando uno de los repetidos fundamentos de la retórica cristiana; lo mismo que su vertiente iconográfica (como el caso de san Pablo, representado con una espada).

Patón emplea, además, la mención de algunos ejercicios militares de la Historia como demostración del triunfo de la fe o de la cruz. El paralelismo, de origen bíblico, siempre ha demostrado su eficacia en la acción pastoral de la Iglesia. Dos son los ejemplos que mejor ilustran la secuencia. El primero, las reiteradas alusiones al emperador Constantino I el Grande, en especial la de su triunfo contra el tirano Majencio y el sueño o visión de la Santa Cruz que le condujo a la victoria («In hoc signo vinces») en la batalla del Puente Milvio y le llevó a convertirse al cristianismo, según la apologética cristiana. El segundo es un episodio de la mitología de la reconquista que el autor recuerda con añoranza: «la milagrosa batalla de Las Navas de Tolosa», y la intercesión o visión de otra cruz en el cielo, que fue la que guio a las tropas cristianas en la victoria final contra los infieles. No son despreciables las ilustraciones. Aunque el apunte es breve, con ellas se enseña que la devoción a Cristo mueve montañas: es capaz de vencer al enemigo más encarnizado, elevar la moral del guerrero o convertir a los paganos. Pensemos que el argumento no era nada novedoso para los fieles de la época. Santos luchadores como san Jorge, san Miguel o, sobre todo, Santiago, ya formaban parte del imaginario colectivo; y conocidas órdenes religioso-militares y algunas religiones mendicantes, son mencionadas por el Maestro por su empeño en la defensa del cristianismo, con sus cruces grabadas en el pecho.

50 Ortega-Costa, 1978: 109. Fue apresada en 1532 y torturada hasta que se la condenó en diciembre de 1532 por "alumbrada» y «luterana».
La cuestión militar se convierte así en un recurso acreditado y provechoso de adoctrinamiento social, al tiempo que la presentación de episodios históricos donde la cruz orbitaba como centro casi exclusivo de la devoción cristiana, también nos mostraba a una Iglesia militante y triunfadora. En algunos casos se procede con descripciones tremendamente efectistas, visuales, o directamente graciosas, como las cruces que aparecieron en los vestidos de los judíos y que estos no se podían quitar o los episodios de las cruces tatuadas, o «labradas a fuego" en algunas partes del cuerpo de los infieles, como en el caso de los moros de la Cabilia argelina llamados azuagos (siglo XVI), quienes la llevaban marcada en la mejilla derecha como señal distintiva de su fe, al considerarse descendientes de cristianos (vándalos); o el de un ejército turco que sirvió de presente del rey persa Cosroes II al emperador bizantino Majencio por su ayuda militar en una guerra de sucesión, quienes la llevaban marcada sobre la frente. Contaban satisfechos los otomanos que la marca les había ayudado a vencer una epidemia de peste. Episodio que nos remonta a los libros bíblicos del Apocalipsis y de Ezequiel, donde se cuenta cómo marcaban con un sello en la frente a los servidores de Dios (Apocalipsis 7, 3; 9, 4; 13, 16 y $14,1)$; pero sobre todo a la conversión del infiel, que es lo que interesa, más si se tiene en cuenta que estos aborrecían la cruz y las imágenes como se afirma (fol. 26v). A pesar de que la resistencia de los conversos ya era mínima o nula, todavía Patón exterioriza su animadversión hacia lo diferente, como suele ser habitual en su época, arremetiendo contra los que acusa de seguir practicando sus ritos camuflados: «infieles que andan encubiertos entre nosotros de cometer en ellas algunas blasfemias hereticales con oprobio de golpes y otros géneros de desprecio» (fol. 26). Con lo que pretendía advertir al buen cristiano de los peligros de la herejía, contraria a la unidad de la Iglesia, que tanto predicaba.

Algunos de estos episodios del triunfo de la Cruz Santa y otros eran comunes y podían estar presentes en la conciencia de los fieles por obra de los sermones, de algunas diversiones como el teatro, de la pintura o de disertaciones como la nuestra u otras, y consiguen reforzar la idea del cristiano que forma parte de una milicia cuyo único capitán es Cristo, e inciden en la percepción de la licitud de la guerra en la línea del tópico paulino, común en la predicación sagrada. El léxico aplicado favorece esa idea: «porque es trofeo del mismo Cristo Dios hombre, freno y asombro del diablo, armas de los cristianos, escudo que rechaza las flechas del enemigo demonio, celada que defiende la cabeza, loriga y peto que ampara la persona, señal de victoria» (fols. $27 v-28$ ). La máxima expresión de este pensamiento vendría simbolizada por la Compañía de Jesús, por la que sentía particular admiración, y a la que se acude para ilustrar algunos ejemplos.

Desarrollada, pues, con contundencia esta doctrina emparentada con el miles christianus, la idea se desliza subrepticiamente en el cauce de la vida cotidiana española; pero como no se puede pasar por alto la fuerte implantación de la religión en todas las capas de la sociedad, a nuestro soldado cristiano no le quedaba más remedio que obedecer. Ese era su cometido. El discurso de la Decente colocación representa, pues, una piedra más en la dirección de control del pensamiento, pero también de prácticas. Como apunta Caro Baroja es posible que aquí, «en la unidad forzada por el Estado [...] 
que produce el clericalismo español» se encuentren las raíces de un mal endémico en España. ${ }^{51}$ Para otros, es el síntoma más palpable de la decadencia de la religiosidad española, después de la eclosión de vitalidad, intensidad, creatividad o reformismo de la primera mitad del siglo XVI.

El entramado ideológico, no obstante, se adereza con abundantes citas que sostienen las opiniones más variadas. Según Madroñal, las citas de autoridad constituyen un rasgo típico del humanista contrarreformista. ${ }^{52}$ Además, Patón, cuyo dominio del latín era evidente por sus traducciones y comentarios de autores clásicos, acude a todo tipo de autoridades civiles o religiosas, en latín o en romance, como sustrato legislativo, doctrinal o erudito en apoyo de su disertación y, por supuesto, de la iglesia jerárquica.

Las ejemplificaciones son muy variadas y no todas hacen referencia expresa al símbolo sagrado. Basta con que acudan en auxilio de algún determinado pensamiento al que refuerzan en su tesis. Entre las autoridades civiles, por un lado, se tiene especial predilección por los emperadores romanos (Adriano, Constantino, Tiberio II, Justiniano I, Teodosio II y Valentiniano III), porque se entiende que, bien por su trayectoria o por algunos acontecimientos históricos relacionados con el madero o su legislación, ilustran con su jerarquía la calidad de los argumentos; por otro, se tienen en cuenta las fuentes clásicas, en algunos casos, para ilustrar con máximas concretas (Pitágoras, Virgilio, Cicerón); en otros, para ejemplificar las prácticas de la Antigüedad, desde un punto de vista satírico (Persio, Horacio) o serio (el soldado cristiano de Tertuliano).

En cuanto a las autoridades religiosas, estas nos pueden servir, secundariamente, para conocer el entramado de amistades del manchego y su correspondencia con destacados priores, clérigos u obispos de la época (fray Alonso Santillán, fray Domingo Nieto, fray Luis Beltrán, fray Jerónimo Román...), al tiempo que nos revelan las preocupaciones o las prácticas de estos sobre el uso de la cruz. Otros contemporáneos relevantes en el ámbito cultural nos acercan acontecimientos históricos (la prohibición de las crucifixiones en tiempos de Constantino, recogido por J. Creso en su importante De cruce) o simplemente curiosos (los santantones de la universidad de Salamanca para ahuyentar a los groseros que recuerda Antonio de Nebrija).

De más calado son las notas que se extrae de la máxima autoridad escrita, la Biblia, por su amplitud y por lo que suponía para un cristiano de la época su mención. Algunas de las citas incluso ilustran la portada del libro y muestran en metáfora la devoción que debe sentir todo cristiano hacia los símbolos sagrados (Cantar de los Cantares, Carta a los Gálatas). Otras abundan en el aspecto militar (Sabiduría, Efesios) o devocional (Josué, Jeremías, Timoteo, Isaías...). Abundantísimos y variados son los ejemplos de los doctores de la Iglesia (san Jerónimo, san Ambrosio, san Juan Crisóstomo, san Juan Damasceno...) u otras figuras del santoral (san Pablo, san Marcial, san Bernardo, santa Elena, santo Toribio, san Agustín, san Francisco de Asís...), la mayoría sobre las virtudes de la cruz otros sobre la devoción del cristiano, la herejía o el demonio, como en el caso de la de la virgen Eustoquia que relata san Jerónimo.
En el aparato legal, además del edicto de la Inquisición, cabe citar la importante recopilación de derecho romano, el Códice Justiniano (534), y otras disposiciones de orden religioso en auxilio del buen uso de la cruz, como el concilio Trullano (680-681), el Concilio II de Nicea (787), el Corpus luris Canonici (1503), los sínodos de san Juan de Ribera (1578) o san Carlos Borromeo (1599).

Como colofón, resulta, a ojos de hoy, difícil comprender toda esta sucesión de desvelos por parte de la clase social más poderosa, preocupada por una religiosidad que había degenerado en superficial, férreamente controlada y de aparatosa ostentación, al tiempo que mostraba su gran negocio y preocupación: la salvación del alma. «Con esto, pienso, habré satisfecho a todas las dudas que nos proponen estos días» (fol. 23), concluye don Bartolomé.

\section{LA DEVOCIÓN DE LA CRUZ (CALDERÓN DE LA BARCA)}

Lejos de las prohibiciones, los lugares comunes y los tratados de cruce, las representaciones de la cruz podían adquirir otras posibilidades, igualmente válidas incluso hoy en día, y muy conocidas por el pueblo. Para la literatura de la época, especialmente para las comedias hagiográficas, supuso un excelente material dramático. Me voy a referir en esta última parte del artículo a una comedia de Calderón de la Barca donde la cruz como escudo espiritual o emblema redentor se convierte en eje central de la acción: La devoción de la cruz, una de sus obras más famosas, publicada en su Primera Parte de Comedias (1636). El texto no deja de ser también apologético, pero su obligado docere teatral fija el mensaje de manera más asequible y quizás efectiva sobre la conciencia de los espectadores.

De ambiente 'bandoleril', plantea el complicado tema de la salvación de los malhechores, tal como se concebía también en El condenado por desconfiado, de Tirso de Molina, con implicaciones muy parecidas. Este tipo de subgénero religioso de comedias de santos y bandoleros, esbozaban casi siempre un mismo argumento donde se enfrentaban, en un mismo personaje, el pecado y el perdón, la culpa y la gracia divina. La posibilidad de redención de pecadores que habían llevado una vida al margen de la ley, ha dado mucho jugo en la historia de la literatura, y en el teatro áureo se convierte en un motivo recurrente. Aparece en personajes de todo tipo, y es característico de aquellos que truecan una trayectoria licenciosa en otra de santidad. Pero el hecho diferencial en Calderón con respecto a estos ejemplos, radica precisamente en el empleo y significado de la cruz, tal como nos orienta el título, y como se verá más adelante.

Las posibilidades salvíficas que atribuye el dramaturgo madrileño a este sagrado símbolo son parecidas a las que manifestaba Patón y se reproducían más arriba, aunque aquí adquieren un mayor alcance teológico:

\section{Árbol donde el cielo quiso dar el fruto verdadero ${ }^{53}$ contra el bocado primero; flor del nuevo paraíso, arco de luz, cuyo aviso}

\footnotetext{
$51 \quad$ 1978: 183.

$52 \quad 2009 b: 362$.
}

53 La simbología del árbol de la cruz ha dado pie a varios títulos de comedias, como veremos más adelante. 
en piélago más profundo

la paz publicó del mundo;

planta hermosa, fértil vid,

arpa del nuevo David,

tabla del Moisés segundo.

Pecador soy; tus favores

pido por justicia yo,

pues Dios en ti padeció

sólo por los pecadores. ${ }^{54}$

Este pasaje, justamente famoso, sobre la simbología de la cruz, está puesto en boca de Eusebio, personaje principal, bandolero acusado de numerosos crímenes, pero arrepentido al final. El mensaje de la obra a ojos de cualquier espectador de un corral de comedias podía aparecer diáfano: el perdón divino es infinito, los crímenes más horrendos pueden ser perdonados si hay arrepentimiento o, como en este caso, devoción a la cruz. Aunque, como en otras obras de Calderón, el texto admitiría hoy varias lecturas, no es el propósito de este artículo ahondar en cuestiones metafísicas o dudas angustiosas sobre la salvación, todas de hondo calado teológico.

Volvamos al hecho diferencial comentado más arriba. El argumento presenta a dos hermanos, Eusebio y Julia, que nacen en medio del monte al pie de una cruz, ambos con unas señales o marcas en forma de cruz grabadas en el pecho. El primero, de naturaleza violenta, es abandonado y termina convirtiéndose en capitán de bandoleros; la niña es criada por su madre. Toda la obra muestra el respeto reverencial de Eusebio hacia la cruz, ante cuyo recuerdo o visión se detiene y venera (como en los duelos): cree que le ha salvado de morir varias veces; manda poner cruces ante los sepulcros de sus víctimas; e incluso impide el incesto cuando, enamorado de Julia sin saber que es su hermana, iba a forzarla en el convento donde estaba recluida. La visión del símbolo grabado en el pecho obró el milagro. Si se salva el malhechor al final, ascendiendo a los cielos, no es solo por este respeto a la cruz, sino por confiar en Dios e invocar antes de morir el auxilio de un ermitaño al que anteriormente le había perdonado la vida. El milagro se ha producido: la devoción de la cruz ha obrado el cambio y su redención. El final es apoteósico e incluye el ascenso a los cielos de los amantes en espectaculares efectos voladores. Curioso es el caso de Julia que sube al cielo "asida de la cruz que está en el sepulcro de Eusebio» (v. 2573+), cuando su padre se disponía a matarla.

Llegados a este punto se hace necesario recordar algunas fuentes que debieron influir en el pensamiento de Calderón y que completan la iconografía de la representación que se viene comentando a lo largo de este artículo. Me estoy refiriendo a unas conocidas palabras de san Efrén, que recoge Pedro Rivadeneyra en su Primera parte del Flos Sanctorum:

Pintemos en nuestras puertas y en nuestras frentes, en la boca, en el pecho y en todos nuestros miembros la vivífica señal de la Cruz. Armémonos con esta armadura impenetrable de los cristianos, porque la Cruz es la victoria de la muerte, esperanza de los fieles, luz del mundo, llave del paraíso, cuchillo de las herejías... ${ }^{55}$

$54 \quad$ Ed. Manuel Delgado, vv. 2276-2289.

55 1624: 330. El catecismo de la doctrina cristiana, de Jerónimo de Ripalda (1591), recoge los mismos principios.
Aunque este fragmento debe interpretarse en un sentido más figurado que real, el hecho es que, como refleja la obra de Calderón, se transmitía el mensaje de que la cruz grabada en el pecho protegía contra las tentaciones del demonio; además, al escritor, en este caso, le servía para plantear cuestiones de mayor envergadura como la redención. No se está hablando, pues, de un simple amuleto, la comedia refleja en toda su extensión su importancia, la de la presencia de Dios.

Aparte del texto de Rivadeneyra y san Efrén se han señalado también otras posibles fuentes de tratadistas espirituales que también ilustraban sobre prácticas diversas en cuanto a la devoción de la cruz, como el caso del franciscano fray Alonso de la Cruz con sus Discursos evangélicos y espirituales (1599). Sin duda que hay más.

Fuera del ámbito de los personajes criminales y devotos, oxímoron bien barroco, la literatura nos ha legado otros muchos textos donde el símbolo sagrado se convierte en núcleo de la acción. No es intención del artículo repasarlos, quedando el asunto para mejor ocasión. No obstante, no quiero dejar de mencionar, para terminar, algunos títulos que también operaban en el espectador similares doctrinas. El propio Calderón, tan habituado a la teología dramática, nos ofreció dos buenos ejemplos más: la comedia $L a$ exaltación de la cruz (publicada en 1652), de materia histórica pero de objetivo pragmáticamente religioso, donde se dramatiza la derrota del rey persa Cosroes (Cosdroas en el impreso) ante el emperador bizantino Heraclio; y el auto sacramental El árbol del mejor fruto, cuyo argumento principal gira en torno a la leyenda del árbol de la cruz, y cuyos protagonistas son Salomón y la reina de Saba. ${ }^{56}$ Títulos en los que se encuentran mezclados asuntos de fondo histórico con implicaciones espirituales e incluso sobrenaturales con el leño sagrado como centro.

\section{BiBLIOGRAFÍA}

Alonso, D. 1977. «...Si no le viera la cruz. Nota gongorina». Homenaje al Prof. Muñoz Cortés, Vol. 1: 27-35.

Arellano, I. 2008. «El árbol del mejor fruto de Calderón y la leyenda del árbol de la cruz. Contexto y adaptación». Anuario calderoniano, 1: 27-65.

Bonilla y san Martín, A. 1914. «El bachiller de Arcadia y el capitán Salazar». Boletín de la Real Academia de la Historia, 65: 516-523.

Calderón de la Barca, P. 2000. La devoción de la cruz, ed. Manuel Delgado. Madrid: Cátedra.

Caro Baroja, J. 1978. Las formas complejas de la vida religiosa (siglos XVI y XVII). Madrid: Akal.

Cervantes, M. 1920. Rinconete y Cortadillo, ed. crítica F. Rodríguez Marín. Madrid: Tipografía de la «Revista de Archivos, Bibliotecas y Museos».

Constituciones sinodales hechas y promulgadas en el primer sínodo que se celebró en la ciudad y obispado de Valladolid. 1803. Valladolid: Pablo Miñón.

Correas, G. 2000. Vocabulario de refranes y frases proverbiales, ed. digital R. Zafra. Pamplona-Kassel: Universidad de Navarra-Reichenberger.

56 Véase Arellano «El árbol del mejor fruto de Calderón y la leyenda del árbol de la cruz. Contexto y adaptación». Existe una comedia del mismo título a nombre de Tirso de Molina de 1621 de argumento diferente, con los hechos del emperador Constantino como núcleo central, pero sobre la misma victoria de la cruz. 
Chevalier, M. 1999. Cuento tradicional, cultura, literatura (siglos XVIXIX). Salamanca: Universidad de Salamanca.

Denzinger, H y P. Hünermann 2006. El magisterio de la Iglesia. Enchiridion Symbolorum definitionum et declarationum de rebus fidei et morum. Barcelona: Herder.

Entremeses Nuevos de diversos autores para honesta recreación. 1643. Alcalá de Henares: Francisco Ropero. Edición Juan C. González Maya. 2012. Newark: Juan de la Cuesta.

Fernández Collado, A. 2000. Obispos de la provincia de Toledo (15002000). Toledo: Estudio Teológico de san Ildefonso.

Garau, J. 2011. «Editar a Bartolomé Jiménez Patón (A propósito de una edición reciente)». Criticón, 111-112: 273-285.

- 2012a. «Ideas religiosas del Maestro Bartolomé Jiménez Patón (1569-1640) en El virtuoso discreto (c. 1629-1631)». Hispania Sacra, 129: 237-258.

- 2012b. «No hay mayor desigualdad que hacerlo todo igual. Sobre el Discurso de Bartolomé Jiménez Patón en defensa de los estatutos de limpieza». Bulletin Hispanique, 114: 597-620.

Gómez Canseco, L. 1993. El humanismo después de 1600: Pedro de Valencia. Sevilla: Universidad de Sevilla.

Góngora y Argote, L. 1967. Obras Completas, ed. Juan e Isabel Millé y Jiménez. Madrid: Aguilar.

Jiménez Patón, B. 1635. Decente colocación de la Santa Cruz. Cuenca: Julián de la Iglesia.

- 2010. Comentarios de erudición (Libro decimosexto). Ed. C. Bosch, J. Garau, A. Madroñal y J.M. Monterrubio. Madrid-Frankfurt am Main: Iberoamericana-Vervuert-CSIC

Kamen, H. 2004. La Inquisición española. Una revisión histórica. Barcelona: Crítica.

Lida, R. 1958. «De Quevedo, Lipsio y los Escalígeros», en Letras Hispánicas: estudios, esquemas. México: Fondo de Cultura Económica, pp. 157-162.

López de Haro, A. 1622. Segunda parte del Nobiliario genealógico de los reyes y títulos de España. Madrid: Viuda de Fernando Correa de Montenegro.
Madroñal Durán, A. 2009a. Humanismo y filología en el Siglo de Oro. En torno a la obra de Bartolomé Jiménez Patón. Madrid-Frankfurt am Main: Iberoamericana-Vervuert.

- 2009b. "Modelos del perfecto humanista en el siglo XVII», en Las enciclopedias en España antes de l'Encyclopédie, ed. Alfredo Álvar Ezquerra. Madrid: CSIC.

Nebrija, E.A. 1504. Aelii Antonii Nebrissensis Grammatici in A. Persivm Flaccvm Poetam satyricvm interpretatio. Sevilla: lacobus Kromberger.

Núñez Beltrán, M.A. 2000. La oratoria sagrada de la época del Barroco. Doctrina, cultura y actitud ante la vida desde los sermones sevillanos del siglo XVII. Sevilla: Universidad de Sevilla-Fundación Focus Abengoa.

O’Neill, Ch. E. 2001. Diccionario histórico de la Compañía de Jesús. Madrid: Universidad Pontificia Comillas.

Ortega Costa, M. 1978. Proceso de la Inquisición contra María de Cazalla. Madrid: FUE.

Paz y Melia, A. 1890. Sales españolas o Agudezas del ingenio nacional. Madrid: Imp. y Fundición de M. Tello.

Persio Flaco, A. y D.J. Juvenal. 2008. Sátiras Juvenal, Persio, ed. Rosario Cortés Tova y Manuel Balasch. Madrid: Gredos.

Quevedo, F. 1932. Obras completas de Francisco Quevedo. Obras en verso, ed. crítica L. Astrana Marín. Madrid: Aguilar.

Rivadeneyra, P. 1624. Primera parte del Flos Sanctorum, o libro de las vidas de los santos. Madrid: Luis Sánchez.

Rodríguez, L.E., P. Bezares y J.L. Polo. 2004. Historia de la Universidad de Salamanca II. Estructuras y flujos. Salamanca: Universidad de Salamanca.

Rodríguez Marín, F. 1920. Un millar de voces castizas y bien autorizadas que piden lugar en nuestro léxico. Madrid: R. de Archivos.

Rosal, F. 1976. La razón de algunos refranes. Alfabeto tercero y cuarto de Origen y etimología de todos los vocablos de la lengua castellana, ed. B. Bussell Thompson. London: Tamesis Books.

Valencia, P. Varios papeles sacados de un Tomo en folio que contenía varias obras de Pedro de Valencia. Madrid: BNE, Ms. 11160.

Varo Zafra, J. 2010. «Diego Hurtado de Mendoza y las "Cartas de los bachilleres"». Castilla. Estudios de Literatura, 1: 433-472. 